\section{Repeated anovulatory follicles: Transvaginal aspiration as a treatment for temporary infertility}

\author{
Ingrid Brück-Bøgh', S. B. Larsen ${ }^{2}$ and T. Greve ${ }^{l}$ \\ ${ }^{1}$ Section of Reproduction, Department of Clinical Studies, The Royal \\ Veterinary and Agricultural University, Frederiksberg C. \\ 2 Højelse Dyreklinik, Lille Skensved, Denmark.
}

\section{Summary}

The technique of transvaginal ultrasonographic aspiration was repeatedly used in a temporarily infertile mare for the evacuation of one anovulatory follicle occurring during two breeding seasons. The mare reassumed normal ovarian activity immediately after each aspiration with an ovulation detected on the $5^{\text {th }}$ and $14^{\text {th }}$ day, respectively. The mare conceived 9 weeks after the first aspiration to an oocyte ovulated from the ovary opposite the one aspirated. After the second aspiration, the mare did not conceive, probably because of low sperm quality. It can be concluded that transvaginal ultrasonographic aspiration provided a rapid and elegant method for the removal of anovulatory follicles, allowing immediate return to normal ovarian cyclicity. The differential diagnoses of enlarged follicular structures are disiscussed.

keywords:

Anovulatory follicle, transvaginal aspiration, ultrasonography, equine, temporary infertility

Wiederholte anovulatorische Follikel: Transvaginale Aspiration zur Behandlung von temporärer Infertilität

Mit Hilfe von Ultrasonographie wurden in einer Stute während zwei Zuchtsaisons jeweils ein anovulatorischer Follikel diagnostiziert. Die Stute war zu diesem Zeitpunkt 16 bzw. 18 Jahre alt und hatte bis dahin 11 bzw. 12 Fohlen geboren. Die anovulatorischen Follikel hatten offenbar keinen hemmenden Effekt auf die Follikelanbildung an den Ovarien, verhinderten jedoch deren Ovulation. Wiederholte Gonadotrophin- und Progesteronbehandlungen waren ohne Erfolg. Beide anovulatorischen Follikel wurden unter Sedation der Stute mit Hilfe transvaginaler ultrasonographischer Aspiration evakuiert. Das Aspirat war rotbraun, dünnflüssig, geruchlos und beinhaltete geringe Mengen Sediment. Die Progesteronkonzentrationen des Aspirates betrugen 5.4-9.8 ng/ml. Die Stute nahm nach beiden Aspirationen die normale ovarielle Aktivität wieder auf und ovulierte innerhalb von 5 bzw. 14 Tage vom gegenüberliegenden Ovar. Die Stute konzipierte 65 Tage nach der ersten Aspiration und gebar ein lebendes Fohlen termingerecht. Der zweiten Aspiration folgend wurde die Stute während 3 Brunstperioden mit Gefriersperma erfolglos besamt. Auch mehrere andere Stuten, die mit dem gleichen Gefriersperma besamt wurden, konzipierten nicht. Es erwies sich, daß die fehlende Konzeption nach der zweiten Aspiration mit ziemlicher Sicherheit auf mangelhafter Spermaqualität beruhte. Die vorliegende Studie zeigt deutlich, daß die ultrasonographische Aspiration eine schnelle und elegante Methode zur Entfernung anovulatorischer Follikel bei der Stute liefert und damit eine sofortige Rückkehr zur normalen Zyklizität erlaubt. Die möglichen Differentialdiagnosen und die in der Literatur vorkommenden, verschiedenen Definitionen in der Klassifikation von persistierenden follikulären Strukturen am Ovar der Stute werden diskutiert.

Schlüsselwörter: Anovulatorischer Follikel, transvaginale Aspiration, Ultraschall, Pferd, Infertilität

At the beginning of the breeding season in 1993, the mare came into heat with normal signs of estrous behaviour. During an estrous period in the beginning of april, the mare was presented to the veterinary clinic. The physical examination of the mare's body condition did not show any abnormal findings. There was no evidence of alteration in personality or signs of behavioural changes. Vulva, clitoris and mammary glands appeared normal. Ultrasoundscanning of the reproductive tract revealed edematous endometrium, the presence of intrauterine fluid in a minor degree and of endometrial cysts. Furthermore on the left ovary, the mare presented follicles of approximately $60,45,25$ and $20 \mathrm{~mm}$ in diameter. The mare was treated twice with 1500 


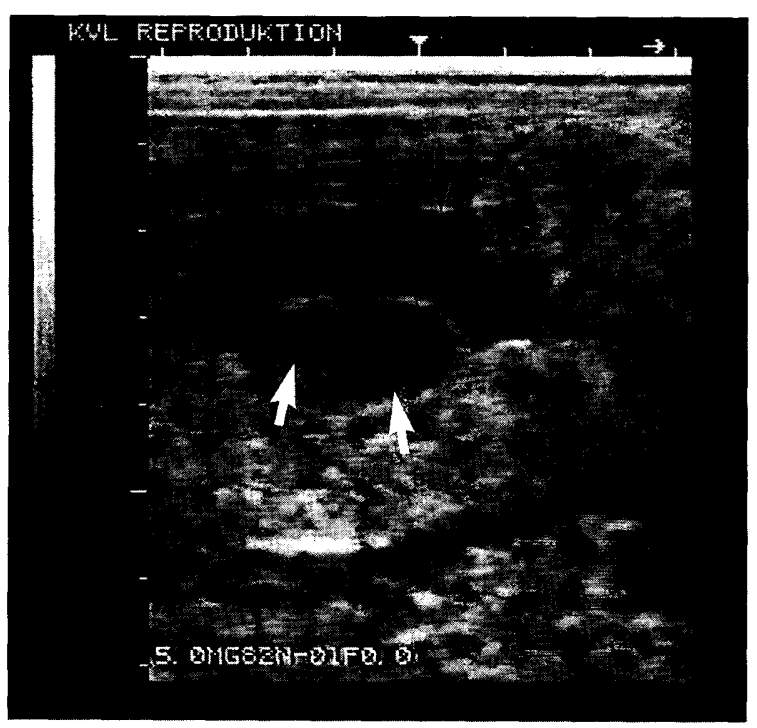

Fig. 1.: Ultrasonographic image of 2 endometrium cysts (white arrows) and intrauterine non-echogenic fluid (black arrow).

Ultraschallbild von 2 Endometriumzysten (weiße Pfeile) und intrauteriner, nicht-echogener Flüssigkeit (schwarzer Pfeil).

i.u. human chorion gonadotrophin $\left(\right.$ Chorulon $\left.{ }^{\circledR}\right)$ and intrauterine with 2 mill. i.u. benzylpenicillin (Novocillin ${ }^{\circledR}$ ), and was subsequently inseminated. Ensuing, the intraluminal fluid disappeared, but ovulation was not observed.

During the following estrous period, the left and right ovaries were estimated rectally to be $12 \times 8 \times 7 \mathrm{~cm}$, and $6 \times 5 \times$ $5 \mathrm{~cm}$, respectively. On the right ovary there was a follicle of approximately $40 \mathrm{~mm}$ in diameter. A large, tense structure presented itself on the left ovary; the ballotment indicated that it was fluid-filled. The uterine tone was low. Ultrasonography revealed the presence of a small amount of intraluminal non-echogenic fluid in the uterus (Fig. 1) and ede-

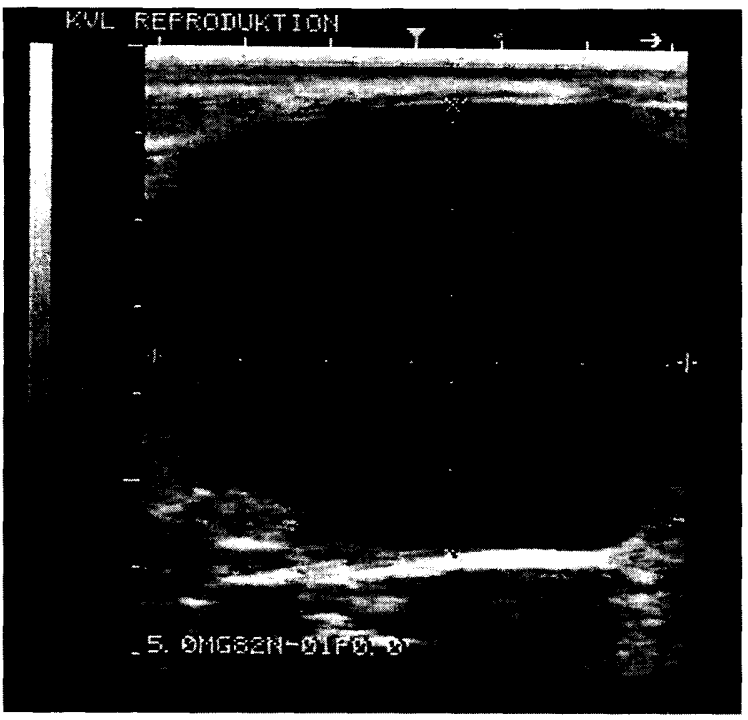

Fig. 2.: Two anovulatory follicles occurring during two different breeding seasons on the left ovary of the same mare (the first to the left, the second to the right).

Zwei anovulatorische Follikel, die während zwei verschiedenen Zuchtsaisons im linken Ovar einer Stute auftraten (der erste links, der zweite rechts). ma in the endometerium. Furthermore, two endometrial cysts of $5 \mathrm{~mm}$ and $12 \mathrm{~mm}$ in diameter, respectively (Fig. 1) were diagnosed. A $62 \times 52 \mathrm{~mm}$ non-echogenic structure dominated the left ovary (Fig. 2). Scanning the structure in a different angle revealed a $22 \times 22 \mathrm{~mm}$ large echogenic structure with a solid base located ventrally within the nonechogenic area (Fig. 3). On the right ovary there was a large follicle, $37 \mathrm{~mm}$ in diameter.

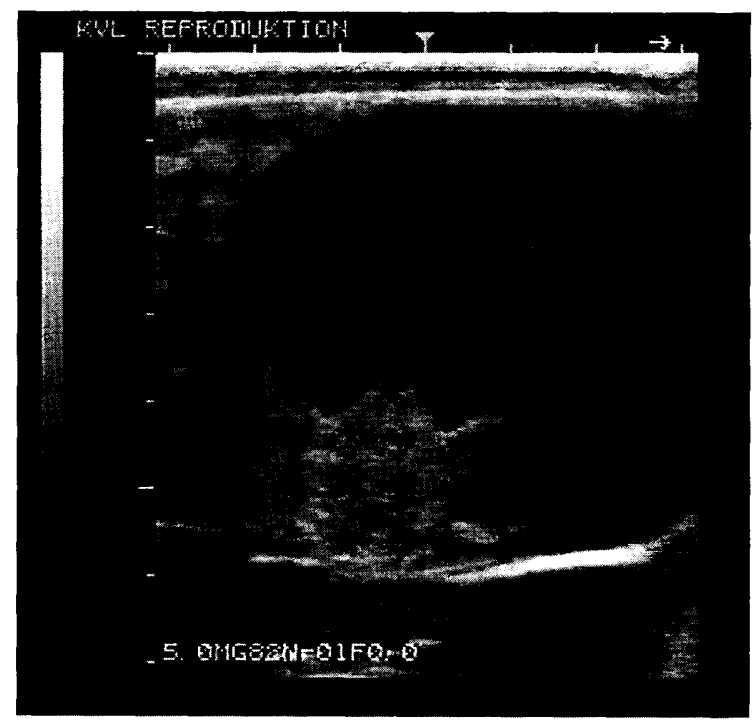

Fig. 3.: Ventral localisation of an echogenic string within the first anovulatory follicle.

Ventrale Lokalisation eines echogenen Stranges innerhalb des ersten anovulatorischen Follikels.

It was decided to evacuate the contents of the fluid filled structure using the technique of transvaginal ultrasoundguided follicular aspiration. The mare received an intravenuous injection of $10 \mu \mathrm{g} / \mathrm{kg}$ bwt detomidinhydrochloride (Domosedan ${ }^{\circledR}$ ), $10 \mu \mathrm{g} / \mathrm{kg}$ bwt atropine and $30 \mu \mathrm{g} / \mathrm{kg}$ bwt acepromazine (Plegicil ${ }^{\circledR}$ ). After 5 minutes, $30 \mu \mathrm{g} / \mathrm{kg}$ bwt butorphanol tartrate $\left(\right.$ Torbugesic $^{\circledR}$ ) was administered for analgesia and $0.15 \mathrm{mg} / \mathrm{kg}$ bwt propantheline bromide for relaxation of the rectum (Bosu et al. 1982; Brück 1991).

The aspiration was performed with a realtime ultrasoundscanner (Aloka SSD 500) equipped with a puncture line and a $5 \mathrm{mHz}$ curved array transducer (Aloka, UST 974-5). The transducer and a $60 \mathrm{~cm}$ long canula were placed inside the aspecially manufactured needle guide (Corometrics Medical Systems, Inc.; Fig. 4). After cleaning of the perianal region, the transducer was placed into the vagina, while the ovary was fixed per rectum towards the anterior fornix of the vagina. When puncture line on the monitor crossed the follicle, the aspiration canula was advanced through the vaginal wall into the follicular cavity (Fig. 5) and the contents was aspirated. Following aspiration the mare was treated with $1.5 \mathrm{mg} / \mathrm{kg}$ bwt flunixin meglumine (Finadyne ${ }^{\circledR}$ ). The protein contents of the aspirated liquid were measured using spectrophotometry. Estrogen concentration in the aspirate was measured with a commercial DPC-kit (Diagnostic Product Cooperation, California, USA) and progesterone concentration was measured by enzyme-linked im- 


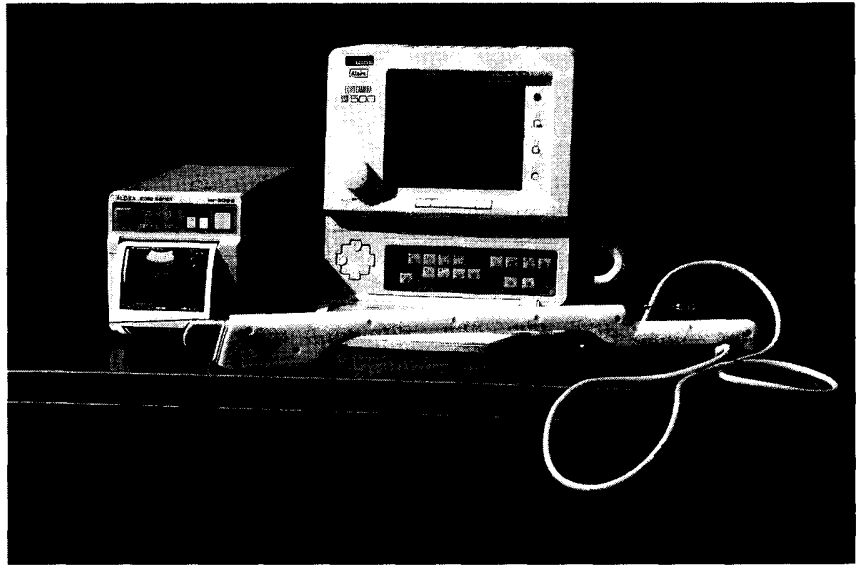

Fig. 4.: Needle guide with curved array transducer (Aloka, UST 974-5) and aspirationcanula.

Ultraschallträger mit Curved array transducer (Aloka, UST 974-5) und Aspirationkanüle.

munosorbent assay (Hoier 1989) modified by diluting the standards with charcoal treated, steroid-free follicular fluid. The follicle on the right ovary had ovulated on the $5^{\text {th }}$ day after aspiration. The mare went subsequently through 3 estrous periods before conceiving (9 weeks after aspiration). During each estrous period, a small amount of sterile intrauterine fluid was observed. The mare was treated twice with 5-10 mill i.u. benzylpenicillin (Novocillin ${ }^{\circledR}$ ) and artifically

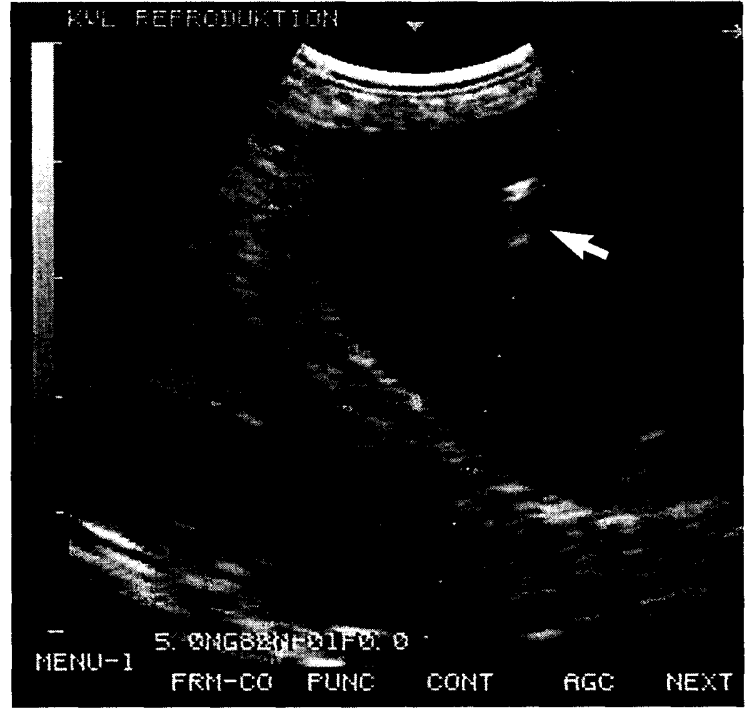

Fig. 5.: Tip of aspiration canula (white arrow) within the cavity of the anovulatory follicle following the puncture line.

Kanülenspitze (weisser Pfeil) sichtbar in der Höhle des anovulatorischen Follikels der Punkturlinie folgend.

inseminated twice during each estrous period. Ovulation occurred in all 3 estrous periods from the right ovary, while there was also activity on the left ovary. The mare was diagnosed pregnant by ultrasonography 8 weeks after the last insemination and foaled a live foal approximately 11 months later.

\section{Ultraschall für Tierärzte}
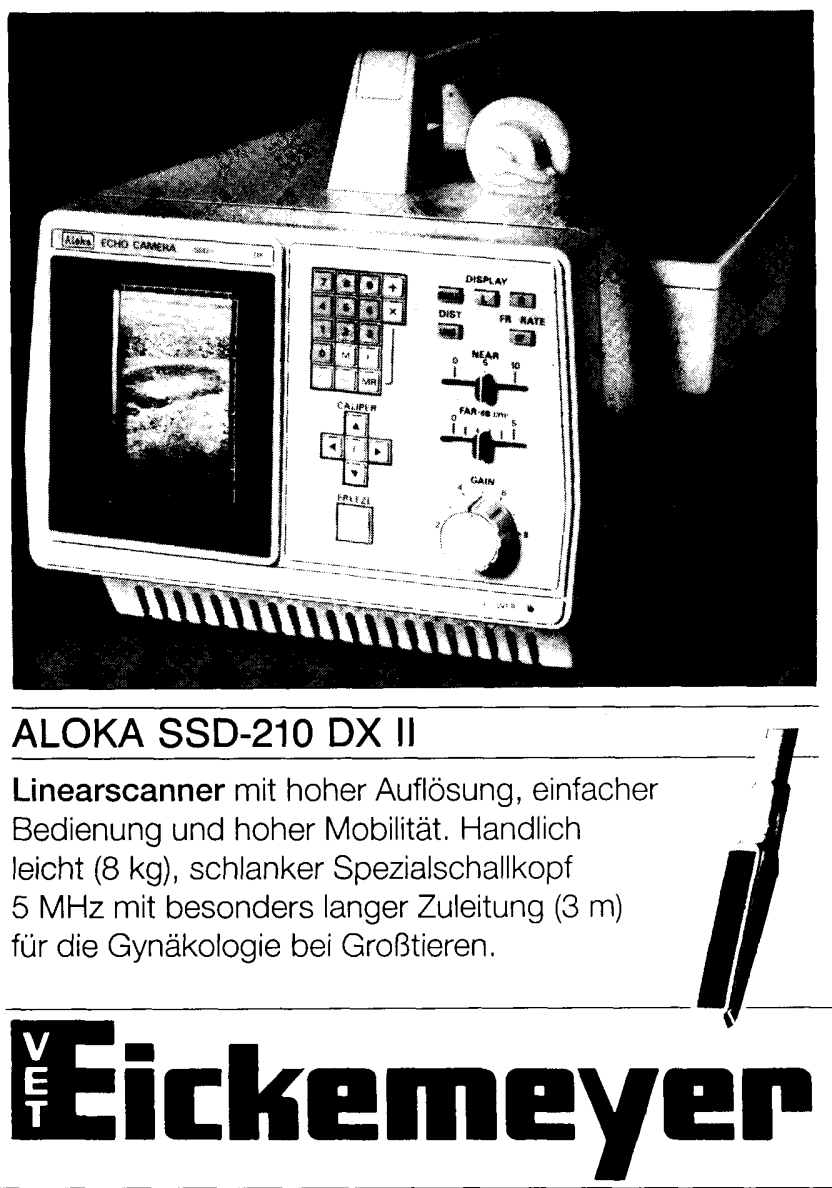

Unser Geräteprogramm, dessen Schallköpfe speziell für die Anwendung bei Groß- und Kleintieren geschaffen wurden.
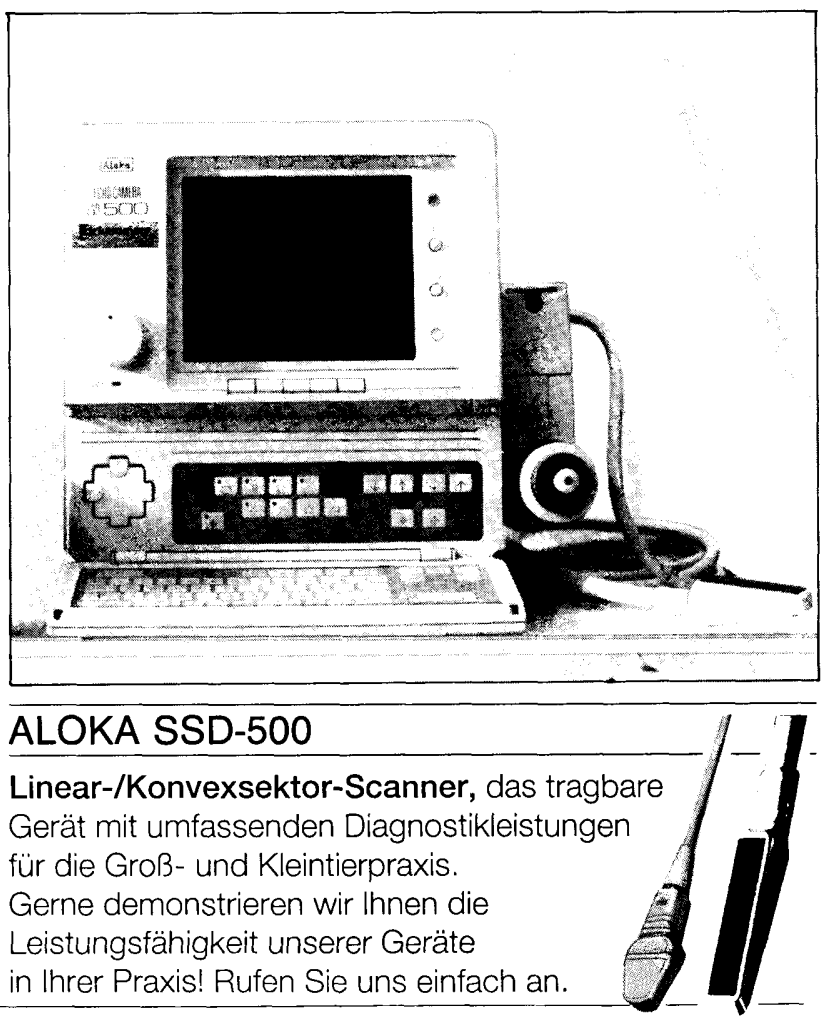

Medizintechnik für Tierärzte

Eltastraße $8 \cdot 78532$ Tuttlingen

Telefon (074 61) $72054 \cdot$ Telefax (074 61) 15740 oder 3905 


\section{Second observation}

In march 1995 (two years after the first presentation), the mare was presented again to the veterinary clinic after having been barren for the end of the previous breeding season inspite of insemination during 3 estrous periods. Ultrasound scanning revealed on the right ovary a round, non-echogenic structure with $39 \mathrm{~mm}$ in diameter and on the left ovary two round, non-echogenic structures with diameters of 30 and $52 \mathrm{~mm}$. There were 5 endometrial cysts present in both, corpus and cornua uteri, and a moderate amount of intrauterine fluid. The uterine endometrium showed clear ultrasonographic signs of estrous edema. A swab taken from the uterine lumen showed no bacterial contamination and the uterus was prophylactically flushed with saline containing 2 mill. i.u. benzylpenicillin $\left(\right.$ Novocillin ${ }^{\circledR}$ ). The mare received 5 i.u. oxytocin (Oxytocin vet ${ }^{\circledR}$ ) twice daily over 3 days. After that period, the signs of the uterine edema were declining and the diameter of the follicle on the right ovary had increased by $3 \mathrm{~mm}$. The mare was treated with 3000 i.E. of human chorion gonadotrophin (Chorulon $\left.{ }^{\circledR}\right)$. After 6 days, the follicle on the right ovary had declined in diameter to $34 \mathrm{~mm}$, the structures on the left ovary remained unchanged. Again, the mare was treated with 3000 i.u.. of human chorion gonadotrophin $\left(\right.$ Chorulon $\left.{ }^{\circledR}\right)$. Four days later the largest follicle on the right ovary measured $20 \mathrm{~mm}$ in diameter, a corpus luteum was not present. The mare was treated with medroxy progesterone (Perlutex ${ }^{\circledR}$ ) for 10 days. The mare was examined regularly during the following 18 days. The ovarian activity during this period did neither result in the presence of a corpus luteum nor a preovulatory follicle, and the large non-echogenic structure on the left ovary remained unchanged (Fig. 2). Once again, it was decided to evacuate the large fluidfilled structure on the left ovary with the technique described above.

Ovulation occurred from the right ovary 14 days after aspiration. During the 3 estrous periods following aspiration, the mare was inseminated with frozen-thawed semen without conceiving. The same batch of frozen semen was used in several other mares and proved to be infertile.

\section{Results}

\section{First observation}

The first aspiration (end of april 1993) resulted in approximately $130 \mathrm{ml}$ redbrown, odorless thin liquor with minor degree of sedimentation. The analysis of the aspirated fluid revealed the presence of $0.46 \mathrm{bill} / \mathrm{l}$ erythrocytes, $0.80 \mathrm{mia} / 1$ leucocytes, $1.60 \mathrm{mmol} / 1$ hemoglobin and $9 \mathrm{~g} / \mathrm{l}$ protein. The measured concentration of progesterone varied between 5.4 and $9.8 \mathrm{ng} / \mathrm{ml}$, as the biological variation was higher than the analytical variation because of the inhomogeneous composition of the sample. The concentration of estradiol-17 was 7 $\mathrm{ng} / \mathrm{ml}$.

\section{Second observation}

During the second aspiration (beginning of may 1995), $150 \mathrm{ml}$ of redbrown, odorless thin liquid was recovered. The analysis of the aspirated fluid revealed the presence of $0.43 \mathrm{bill} / \mathrm{l}$ erythrocytes, $4.40 \mathrm{mia} / \mathrm{l}$ leucocytes, $1.10 \mathrm{mmol} / \mathrm{l}$ hemoglobin and $23 \mathrm{~g} / 1$ protein.

\section{Discussion}

The mare in the present case presented with an anovulatory follicle on the left ovary, which appeared repeatedly during two breeding seasons. The persistance of these anovulatory follicles for more than one estrous cycle caused apparently inhibition of ovulation and removal by transvaginal ultrasoung-guided aspiration was chosen. The technique proved that this mare could be treated with transvaginal ultrasound-guided aspiration.

In our patient, the diagnosis of an anovulatory follicle was put forward on the following clinical findings:

1. Non-echogenic fluid was present inside a follicle-like cavity surrounded by a relatively thin wall.

2. The structure failed to ovulate during at least two, respectively one estrous period, while follicular development seemed unaffected.

3. No behavioural changes.

The diagnosis was supported by the viscous, redbrown aspirate.

The ultrasonographically echogenic areas within the cavity of the first anovulatory follicle are likely to represent fibrinous cords which formed due to hemorrhages. Those arose possibly from lesions in the follicular wall after being exceedingly extended. Also the colour and the hemoglobin concentration of both aspirates implicate that hemorrhage had occurred. The differential diagnoses hematoma and abscess were excluded, since the fluid ultrasonographically lacked the echogenicity typical for these structures. Also the fibrin formation, seen ultrasongraphically as echogenic cords (Ginther and Pierson 1984) was considerably less than it could be expected for a hematoma, which had been present for a minimum of 3 weeks. However, the distinction between an anovulatory follicle and a hematoma depends only on the degree of the intrafollicular bleeding. The possibility of a granulosa-cell tumor was excluded, since the structure was not devided, had a thin wall and the mare's behaviour was unaffected. Granulosa-cell tumors account for most of the ovarian neoplasms in the mare. Their multicystic architecture resemble ultrasonographically follicular structures. In comparison to anovulatory follicles, the cyst walls of granulosa-cell tumors are thicker and can have dimensions of 0.5-1 cm (Førland 1981; White and Allen 1985). Depending on the hormone profile produced and/or caused by a granulosa-cell tumor, the mare's sexual behaviour varies between anestrous, nymphomanic and stallion-like. The moderate progesterone and low estrogen concentrations in the aspirate of the present case were not indicative for a granulosa-cell tumor. 
The mare's cyclic sexual behaviour was not affected. It is plausible that if a sufficient number of estrogen producing follicles develop besides the anovulatory follicle, the mare shows estrous behaviour. Depending on the life span of these follicles and the coinciding estrogen production, the mare will stay in estrus or return to non-estrous behaviour. The anovulatory follicles developing repetitively on the left ovary of this mare did not affect follicular development and estrous behaviour, but obviously prevented ovulation during the observed period. It can not be excluded that this anovulatory follicle already evolved during the preceding autumn and persisted throughout the anovulatory period, or that the mare continued to cycle throughout the entire winterperiod like $20 \%$ of all mares did in a study by $\mathrm{Hug}_{-}$ hes et al. (1980). Furthermore, it is unpredictable, how long the anovulatory period would have lasted, if aspiration would have been refrained, or whether the mares would have ovulated eventually. In a study by Ginther and Pierson (1989), all mares with hemorrhagic follicles ovulated finally, even so the interovulatory interval lasted up to 49 days. Therefore it might be expected that ovulation would have occurred eventually, even without therapeutic aspiration and that the state of infertility was therefore transient. However, with removal of the anovulatory follicles, the mare ovulated within a maximum of 2 weeks, and valuable time was saved.

There is a lack of agreement on the classification of persistent large follicle-like structures on a mare's ovary with the exception of hematomas, abscesses and neoplasms. The variety of diagnoses used in the literature cause confusion: cystic ovaries (Day 1937, Day 1939, Burkhardt 1948), anovulatory follicles (Frazer and Threlfall 1986), hemorrhagic follicles (Ginther and Pierson 1989), anovulatory hemorrhagic follicles (Carnevale et al. 1989), anovulatory follicular cysts (Jubb et al. 1993), autumn follicles (Stangroom and Weevers 1962, Ginther 1992), persisting follicles (Bosu et al. 1982) cystic follicles (Bowen 1968, Sorensen 1979) and ovarian cysts (Forland 1981). The existance of follicular cystic degeneration and cystic ovaries in the mare has even been negated in more recent publications (Allen 1979, Allen 1988, Ginther 1992, McEntee 1990, Jubb et al. 1993).

A description of a cystic ovary as such has only been found in Forland (1981), where an ovary of $17 \mathrm{~cm}$ in diameter with a fibromuscular cystwall of $1 \mathrm{~cm}$ was described in a 4year-old mare. The cyst contents was described as chocolade brown and of low viscosity, and the mare's plasma progesterone concentration was $8.4 \mathrm{ng} / \mathrm{ml}$.

To ease understanding, all other descriptions in the literature of persisting fluidfilled structures on mares' ovaries can be summarized by the following catagories (1) hematomas, (2) abscesses, (3) neoplasms and (4) anovulatory follicles, meaning preovulatory follicles which do not ovulate; these comprise hemorrhagic follicles, anovulatory hemorrhagic follicles, anovulatory follicular cysts, autumn follicles and persisting follicles.

Ginther and Pierson (1989) observed apparent anovulation in $4.7 \%(n=12)$ of all estrous cycles during one ovulatory season of 102 mares. In all cases, a hemorrhagic follicle of up to $90 \mathrm{~mm}$ in diameter was diagnosed by ultrasonography. In 5 cases, prolonged interovulatory intervals of 24-49 days were associated with these hemorrhagic follicles. It could be shown that the incidence was independant of the month. During the first few days, the formation of hemorrhagic follicles was associated with an increase in diameter and the amount of scattered free-floating echogenic spots inside the follicular cavity. Thereafter, the contents became organized with apparent fibrinous cords surrounded by thickened walls.

Cases of anovulation are not restricted to the ovulatory season, but are also a common feature in the transitional period. These anovulatory follicles might reach a size of 10-15 $\mathrm{cm}$ in diameter and persist for up to 2 months before regressing (reviewed by Frazer and Threlfall 1986). Jubb et al. (1993) reported the development of a variable number of anovulatory follicular cysts with different sizes during the winter anestrus. Ginther (1979) described the existance of hemorrhagic follicles in 4 ponymares during fall and suggested that these are probably identical with the so called autumn follicles.

The exact causes of anovulation are unclear, but an imbalance of the mare's hormone profiles is likely to be of importance. Ginther and Pierson (1989) suggested that these anovulatory follicles might evolve from estrogen-deficient follicles. Hormone measurements were not performed in Ginther and Pierson's study (1989), but the ultrasonographic image of the uterine texture indicated a progesterone dominance. In our case, the estrogen concentration of the aspirate was low, supporting this theory. It has also been suggested that anovulation could result from a lack of luteinizing hormone stimulation (reviewed by Frazer and Threlfall 1986). Furthermore, it was possible to induce cystic follicles experimentally feeding mares with progesterone-melengesterol acetate. The cystic follicles persisted througout the entire anovulatory period (Bowen 1968). In another study, 2 anovulatory hemorrhagic follicles occurred after hCG treatment of transitional mares. In these, levels of progesterone remained below $2 \mathrm{ng} / \mathrm{ml}$ by Day 12 post hCG-treatment (Carnevale et al. 1989). Likewise a cystic structure of $10 \mathrm{~cm}$ in diameter has been described in a 4month-old filly. The cystic structure contained, however, a high concentration of total estrogen, and the cystic wall reminded of a follicle under atresia and did not accomodate theca cells (Kenney and Ganjam 1975). On the other hand, Sorensen (1979) described that thickening of the follicular wall of cystic follicles is caused by dense layers of theca cells and fully organized layers of granulosa cells. Inspite of the development of luteal cells in many cystic follicles, which initiate a luteal function, it has been suggested that these luteinized follicles continue to produce estrogens and such, can cause persisting estrous behaviour of the mare.

Transvaginal puncture of large fluidfilled follicular structures was already described by Day in 1937, who performed this technique blind with a trocar. Bosu (1982) reported the surgical exstirpation of 3 ovaries with persisting follicles. All mares started normal cyclicity 15 to 120 days after operation. Evacuations usually resulted in the recovery of thin 
redbrown fluid (Burkhardt 1948, Bosu 1982, Førland 1981).

\section{Conclusions}

The technique of transvaginal ultrasonographic aspiration proved as a rapid and elegant method in order to evacuate anovulatory follicles repeatedly from a mare. While hormone treatment not always leads to immediate success (disappearance of the anovulatory follicles and return to ovulation), the technique described above allowed the mare to be inseminated or served shortly after. Furthermore, the technique allows the aspirate to be collected for later analyses, which could possibly help to elucidate the causes and fate of anovulatory follicles. Not all practitioners will have access to the equipment necessary for ultrasound-guided aspiration. Once, the diagnose has been manifested, these anovulatory follicles can alternatively be aspirated with a long needle via the flank.

\section{References}

Allen, W.E. (1979) Abnormalities in the oestrous cycle in the mare. Vet. Rec. 24,166-167.

Allen, W.E. (1988) Fertility and Obstetrics in the Horse. Blackwell scientific publications, London, 57-58.

Bosu, W.T., van Camp, S.C., Miller, R.B. and Owen, R. ap R. (1982) Ovarian disorders: Clinical and morphological observations in $30 \mathrm{ma}-$ res. Can. vet. J. 23, 6-14.

Bowen, J.M. (1968) An induced cystic ovarian condition in the mare. $\mathrm{VI}^{\text {th }}$ Cong. Intern. Reprod. Anim. Insem. Artif. Paris, Vl II 15591561.

Brück, I. (1991) Propanthelin bromid til hest og kvæg. Dansk Veterinær Tidsskrift 74, 20, 779-780.

Burkhardt, J. (1948) Some clinical problems of horse breeding. Vet Rec. 60, 243-248.

Carnevale, E.M., Squires E.L., McKinnon, A.O. and Harrison, L.A. (1989) Effect of human chorionic gonadotropin on time to ovulation and luteal function in transitional mares. Eq. vet. Sci. 9, 27-29.

Day, F.T. (1937) Sterility in the Mare Associated with Irregularities of the Oestrous Cycle. Vet. Rec. 51, 1113-1126.

Day, F.T. (1939) Some observations on the causes of infertility in horse breeding. Vet. Rec. 18, 581-587.

Frazer, G.S. and Threlfall, W.R. (1986) Differential diagnosis of enlarged ovary in the mare. Proc. $33^{\text {th }}$ Ann. Conv. of Am. Ass. of Eq. Pract. 2128.

Forland, D.A. (1981) Ovarietumor og ovariecyste hos hoppe. Norsk Veterinærridsskrift 93,3
Ginther, O.J. (1979) Reproductive Biology in the Mare: Basic and applied aspects. Cross Plains, Wisconsin, 164-165.

Ginther, O.J. and Pierson, R.A. (1984) Ultrasonic evaluation of the reproductive tract of the mare: ovaries. Eq. vet. Sci. 4, 11.

Ginther, O.J. and Pierson, R.A. (1989) Regular and irregular characteristics of ovulation and the interovulatory interval in mares. Eq. vet. Sci. 9, 4-12.

Ginther, O.J. (1992) Reproductive Biology in the Mare: Basic and applied aspects. Cross Plains, Wisconsin, 224-226.

Høier, R. (1989) Determination of plasma progesterone in the Blue Fox (Alopex lagopus) at pro-oestrus and oestrus by use of a commercial kit. Acta Agric. Scand. 39, 181-186.

Hughes, J.P, Stabenfeldt, G.H. and Kennedy, P.C. (1980) The estrous cycle and selected functional and pathologic ovarian abnormalities in the mare. Vet. Clin. North Am: Large Animal Practice 2, 225-239.

Jubb, K.V.F., Kennedy, P.C. and Palmer, N. (1993) Pathology of Domestic Animals, Academic Press, New York, Vol 3, 360-363.

Kenney, R.M. and Ganjam, V.K. (1975) Selected pathological changes of the mare uterus and ovary. J.Reprod. Fert., Suppl. 23, 335-339.

McEntee, K. (1990) Reproductive Pathology of Domestic Mammals. Academic Press, London, 58.

Rossdale and Ricketts (1974) The Ovaries and pituitary gland, in: The practice of Equine Stud Medicine. Williams and Wilkins Co., Baltimore.

Sorensen, A.M. (1979) Animal reproduction. McGraw-Hill Book Company. New York, 212-213.

Stangroom, J.E. and Weevers, R.G. (1962) Anticoagulant acrivity of equine follicular fluid. J. Reprod. Fert. 3, 269-282.

White, R.A.S. and Allen, W.R. (1985) Use of ultrasound echography for the differential diagnosis of a granulosa cell tumor in a mare. Equine vet. J. 17, 401-402.

Ingrid Brück-Bøgh

Research fellow, Ph. D

Torben Greve

Professor, DVM, Ph.D.

Royal Agriculatural and Veterinary University

Department of Veterinary Clinical Studies

Bülowsvej 13

1870 Frederiksberg $C$

Denmark

Ph.: (45) 35282960

Fax: (45) 35282972

Sten Bo Larsen

Veterinary Practitioner

Hojelse Dyreklinik

Lille Skensued

Denmark

Ph.: (45) 53668022 